M. G. COSTAlES, H. AiKAWA, Y. Li, J. L. CHILDS-DisNEY, D. ABEGG, D. G. HOCH, S. P. VELAGAPUDI, Y. NAKAI, T. KHAN, K. W. WANG, I. YILDIRIM, A. ADIBEKIAN, E. T. WANG, M. D. DISNEY* (THE SCRIPPS RESEARCH INSTITUTE, JUPITER, USA) Small-Molecule Targeted Recruitment of a Nuclease to Cleave an Oncogenic RNA in a Mouse Model of Metastatic Cancer Proc. Natl. Acad. Sci. U.S.A. 2020, 117, 2406-2411.

\section{RIBOTACs - Targeted Degradation of RNA}

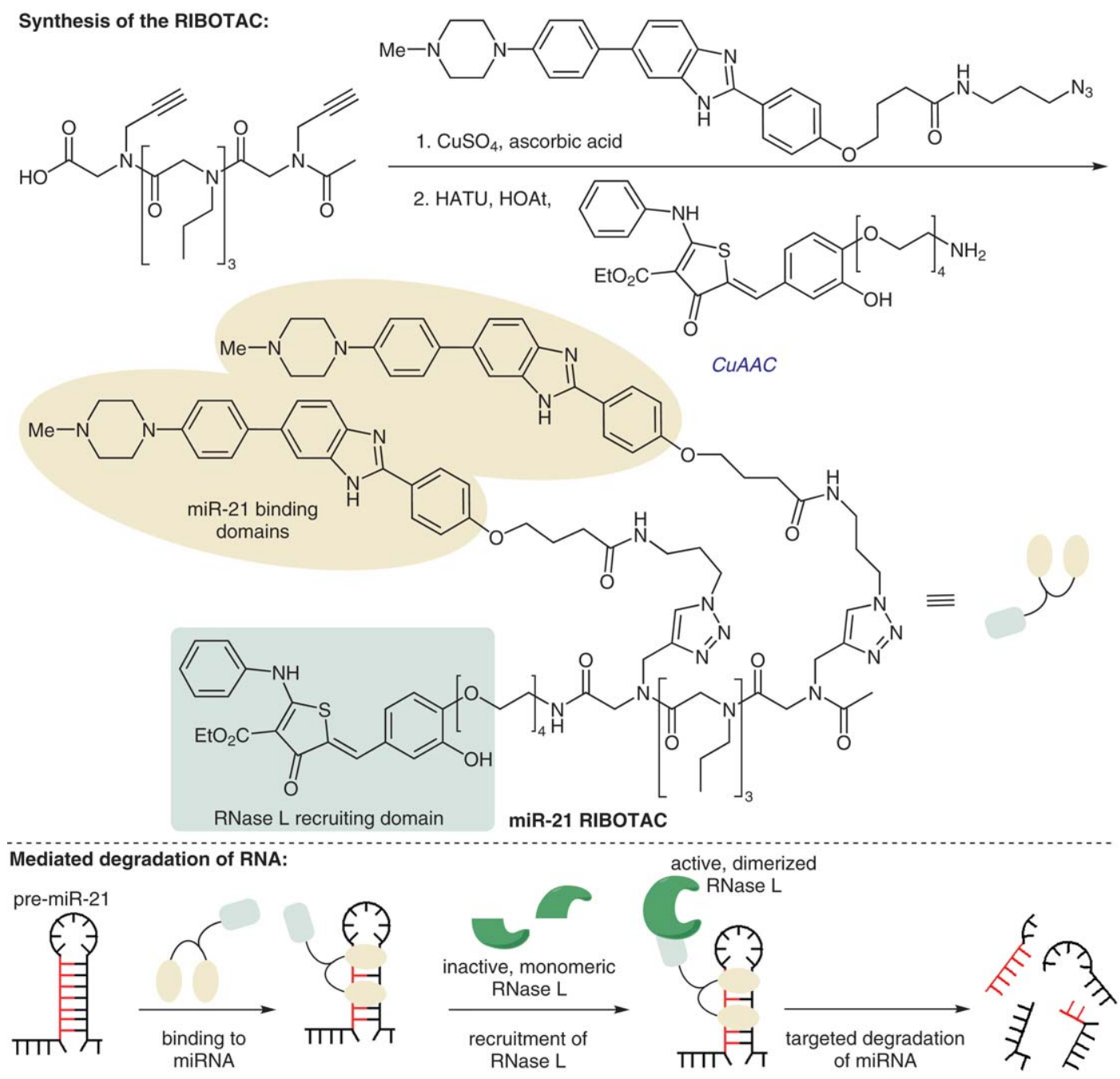

Category

Chemistry in

Medicine and Biology

\section{Key words}

\section{RIBOTAC}

targeted degradation

RNase

miR-21
Significance: Oncogenic micro RNAs are important components of cancer cells since they heavily regulate the expression levels of various proteins. Selective degradation of these miRNAs could be of great potential for cancer therapies. Here, the authors expanded the concept of RIBOTACs, which enables the selective small-molecule targeted degradation of RNA. Mouse models showed inhibition of metastasis progression following administration of miR-21 RIBOTAC.
Comment: The RNA-binding domains and the RNase recruiting fragment were linked to the backbone via copper-catalyzed 'click' reactions and a peptide coupling, respectively. The final RIBOTAC was demonstrated to bind the cancer-causing premiR-21 with great selectivity over other RNA transcripts and was effective in RNase recruitment and target degradation. 